\title{
Tretinoin Liposome
}

National Cancer Institute

\section{Source}

National Cancer Institute. Tretinoin Liposome. NCI Thesaurus. Code C2398.

An intravenous formulation of tretinoin (vitamin A acid or all-trans retinoic acid) encased

in liposomes. Tretinoin is a naturally occurring retinoic acid agent that binds to and activates retinoic acid receptors (RAR), effecting changes in gene expression that lead to cell differentiation, decreased cell proliferation, and inhibition of carcinogenesis. This agent also inhibits telomerase, leading to telomere shortening and eventual apoptosis of certain tumor cell types. Liposome encapsulation extends the half-life of intravenously administered tretinoin. 